\title{
Solitary spinous process metastasis: a case report
}

\author{
Soliter spinöz çıkıntı metastazı: Olgu sunumu
}

\author{
Emre Demirçay, M.D., ${ }^{1}$ Erdinç Civelek, M.D., ${ }^{2}$ Ebru Demiralay, M.D. ${ }^{3}$ \\ ${ }^{1}$ Department of Orthopedics and Traumatology, Medical Faculty of Başkent University, Ankara, Turkey \\ ${ }^{2}$ Department of Neurosurgery, Medical Faculty of Başkent University, Ankara, Turkey \\ ${ }^{3}$ Department of Pathology, Medical Faculty of Başkent University, Ankara, Turkey
}

\begin{abstract}
Vertebral column is a common site for bony metastases in patients with systemic malignancy. Patients with metastatic spinal tumors usually present with pain. Some tumors are asymptomatic and can be detected during screening examinations. Magnetic resonance imaging (MRI) of the vertebral column with the panel of available imagining methods and the clinical findings should be used for the diagnosis of spinal metastasis. A 45-year-old man was admitted with low back pain. With a history of rectum surgery and radiotherapy, he was on chemotherapy for rectum adenocarcinoma. F18 sodium fluoride positron emission tomography scan which was performed three weeks ago showed no abnormalities other than the primary surgical site. Magnetic resonance imaging of the lumbar vertebrae spine revealed a lesion on the tip of L4 spinous process. Excisional biopsy of L4 spinous process was performed. Histologic examination revealed mucinous adenocarcinoma. He had no low back pain at two-months follow-up. We could not find any solitary spinous process metastasis reported in English literature. Patients with nonspecific spinal pain with a previous cancer history should be carefully evaluated for a spinal metastasis. Even a solitary spinous process lesion may turn out to be the initial manifestation of a spinal metastasis. Key words: Bone tissue; low back pain; neoplasm metastasis; neoplasms; spine.
\end{abstract}

Primary malignant tumors frequently metastasize to bone, third in frequency after liver and lung. ${ }^{[1]}$ Breast, lung, prostate, and kidney cancers have been the most common malignancies with secondary spine involvement. ${ }^{[2]}$ Breast and prostate cancers have particular clinical interest because of the prevalence of these diseases, with about $70 \%$ of the
Sistemik malignitesi olan kemik metastazları vertebral kolonda sık görülür. Metastatik spinal tümörlü hastalar genellikle ağrı ile başvurur. Bazı tümörler asemptomatiktir ve tarama muayeneleri sırasında tespit edilebilir. Spinal metastaz tanısında vertebral kolona yönelik manyetik rezonans görüntüleme (MRG) ile birlikte mevcut olan diğer görüntüleme yöntemleri ve klinik muayene bulguları kullanılmalıdır. Kırk beş yaşında bir erkek bel ağrısıyla başvurdu. Rektum cerrahisi ve radyoterapi öyküsü olan hasta rektum adenokarsinomu için kemoterapi almaktaydı. Üç hafta önce yapılan F18 sodyum florid pozitron emisyon tomografisi taramasında primer cerrahi alan dışında bir anormallik yoktu. Lomber vertebra MRG'sinde L4 spinöz çıkıntı ucunda bir lezyon bulundu. L4 spinöz çıkıntıya eksizyonel biyopsi yapıldı. Histolojik inceleme sonucu musinöz adenokarsinom saptandı. İki aylık takipte hastanın bel ağrısı olmadı. İngilizce literatürde daha önce bildirilmiş soliter spinöz çıkıntı metastazına rastlamadık. Geçmişinde kanser öyküsü olan ve nonspesifik spinal ağrısı olan hastalarda spinal metastaz olasılığı dikkatle araştırılmalıdır. Soliter bir spinöz çıkıntı lezyonu dahi spinal metastazın ilk belirtisi olabilir.

Anahtar sözcükler: Kemik dokusu; bel ağrısı; neoplazm metastazı; neoplazmlar; omurga.

patients dying of these cancers having evidence of metastatic bone disease. ${ }^{[3]}$ Bone metastases are also seen in carcinomas of the thyroid, kidney, and bronchus with an incidence of $30-40 \%$ at postmortem examination. ${ }^{[3]}$ However, tumors of the gastrointestinal tract rarely $(<10 \%)$ metastasize to the bone. ${ }^{[3]}$

- Received: April 09, 2012 Accepted: November 13, 2012

- Correspondence: Emre Demirçay, M.D. Başkent Üniversitesi İstanbul Sağlık, Uygulama ve Araştırma Merkezi, Ortopedi ve Travmatoloji Kliniği, 34662 Altunizade, Üsküdar, İstanbul, Turkey. Tel: +90532 - 4335469 Fax: +90 216-4564981 e-mail: emredemircay@hotmail.com 
More than $95 \%$ of spinal metastases are extradural lesions. ${ }^{[4]}$ Most of the remaining lesions are intradural extramedullary tumors, while intramedullary metastases are rare, comprising about $0.5 \%$ of the spinal metastases. ${ }^{[4]}$

Metastatic carcinoma has a predilection for the well vascularized cancellous bone of the vertebral body in the spine; the neural arch is less frequently involved. ${ }^{[5]}$ Metastases occur most frequently in the lumbar spine followed by the thoracic and then cervical spine. ${ }^{[6]}$ Due to the smaller space available for the spinal cord, thoracic lesions are more often symptomatic (70\%), followed by lumbar (20\%), and cervical lesions (10\%). ${ }^{[7]}$ Spinal metastases involve vertebral bodies $(80 \%)$ rather than posterior elements. ${ }^{[8]}$

Pain is the initial symptom in most of the patients. It is usually local but sometimes radicular, radiating in the distribution of the nerve root of the involved level..$^{[9,10]}$ Neurologic compromise in the form of weakness, sensory loss, and sphincter disturbance usually occurs after the onset of pain. Sensory or motor deficits are present in $38-76 \%$ of the patients and half of the patients are nonambulatory at the time of diagnosis. ${ }^{[9,11]}$ The natural history of spinal metastasis is progression to complete irreversible paraplegia if immediate treatment is not undertaken. ${ }^{[12]}$

We report an unusual case of solitary spinous process metastasis of rectal adenocarcinoma.
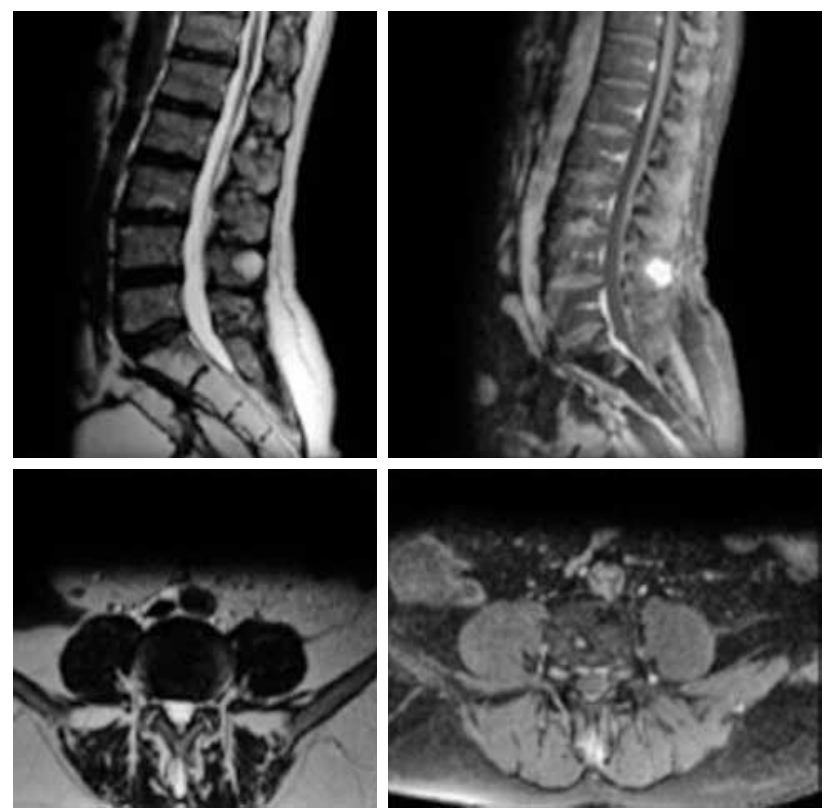

Figure 1. Sagittal and axial magnetic resonance images $\left(T_{2}\right.$ sagittal and axial images on the left side; $T_{1}$ contrast enhanced sagittal and axial images on the right side) showing contrast enhanced lesion in the L4 spinous process.

\section{CASE REPORT}

A 45-year-old man suffering from vague low back pain for three months was admitted to the hospital. His neurological examination was completely normal. He was diagnosed with adenocarcinoma of the rectum three years ago, which was surgically treated with low anterior resection and radiotherapy. Later he developed cerebellar (10 months ago) and lung metastasis (4 months ago). The cerebellar lesion was excised. There was disseminated infiltration in the lung that was not suitable for surgical excision. He was still receiving chemotherapy when he was admitted. His CEA (carcinoembryonic antigen) level was $12.59 \mathrm{ng} / \mathrm{ml}$ (normal: 0-3 ng/ml), CA (carbohydrate antigen) 19-9 level was $101.95 \mathrm{IU} / \mathrm{ml}(0-37 \mathrm{IU} / \mathrm{ml})$. Plain radiography of the lumbar vertebrae was nonspecific. His F-18 sodium fluoride (F-18 NaF) positron emission tomography (PET) done three weeks earlier showed no abnormalities other than the primary surgical site. Magnetic resonance imaging (MRI) of the lumbar spine revealed a $24 \times 21 \mathrm{~mm}$ lesion on the tip of the L4 spinous process. The lesion had low signal intensity on $\mathrm{T}_{1}$, and high signal intensity on $\mathrm{T}_{2}$ and could be seen homogeneously with high signal intensity on contrast enhanced images (Figure 1). Due to anatomic location and size of the lesion open excisional biopsy of the L4 spinous process was performed instead of needle biopsy. Histologic examination revealed mucinous adenocarcinoma (Figure 2). Tokuhashi prognostic score was 11, Tomita prognostic score was 6 . The surgical staging was 1, $12 \mathrm{~A}, \mathrm{~B}$ according to Weinstein, Boriani, Biagini (WBB). ${ }^{[13-15]}$ Technetium-99m (Tc99m) bone scan was nonspecific, showing increased uptake in previously operated sites. There was no low back pain at two months follow-up. Carbohydrate antigen 19-9 and CEA levels were $60.37 \mathrm{IU} / \mathrm{ml}$ and $12.93 \mathrm{ng} / \mathrm{ml}$ respectively.

\section{DISCUSSION}

Back pain is frequent in patients with cancer. ${ }^{[15]}$ The posterior half of the vertebral body is usually involved first, followed by the anterior body, lamina, and pedicles. ${ }^{[16]}$ This is believed to occur by means of two mechanisms: via arterial emboli to the abundant bone marrow of the vertebral bodies and subsequently into the anterior or posterior extradural space thorough venous channels, or via retrograde spread through the valveless extradural Batson's venous plexus. ${ }^{[17]}$

Anteroposterior and lateral plain radiographs of the spine demonstrate abnormal findings in up to $90 \%$ of the patients with symptomatic spinal metastasis. ${ }^{[18]}$ In order to diagnose a metastatic cancer in trabecular bone, 

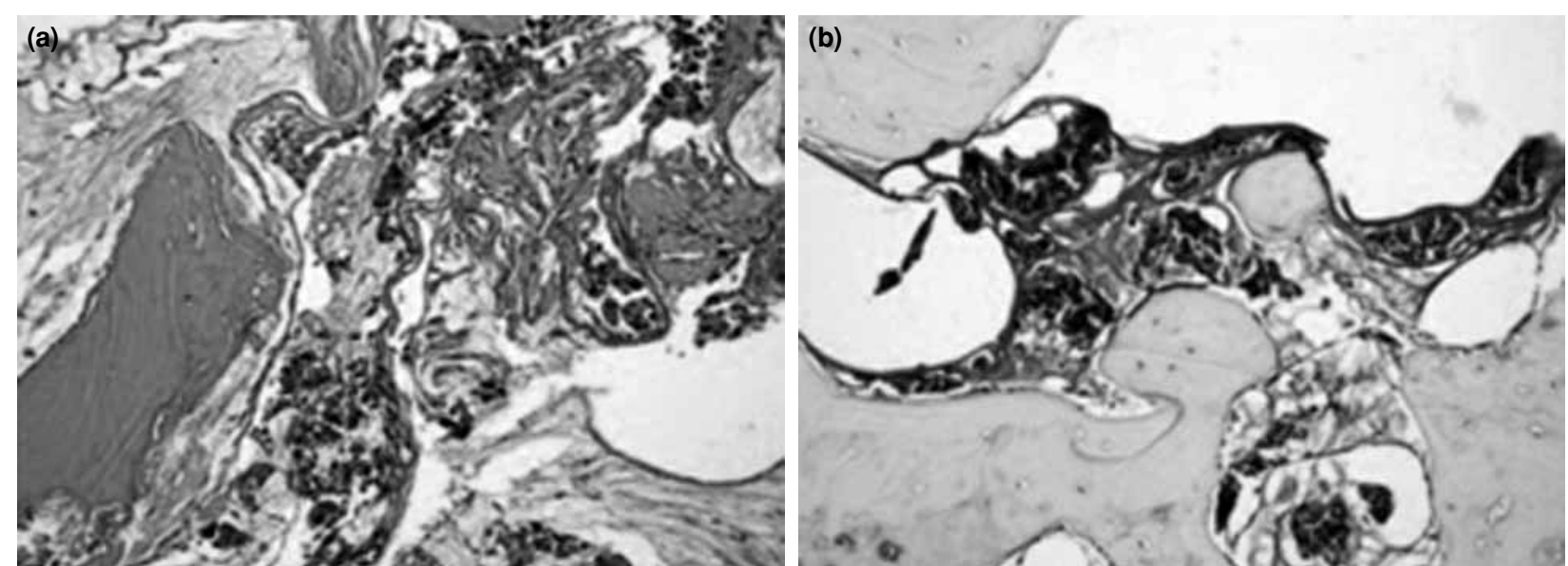

Figure 2. (a) Malignant epithelial cells in the mucinous pools between bone trabeculae $(\mathrm{H}-\mathrm{E} \times 200)$. (b) Carcinoembryonic antigen positive cells in immunohistochemistry (x 200).

$30-50 \%$ bone destruction is required. ${ }^{[19]}$ Scintigraphy, despite its limited accuracy is a good screening tool and can be systematically performed. ${ }^{[1,20]}$ Radionuclide bone scanning using technetium-labeled polyphosphonates was shown to detect bone metastasis several months earlier than plain radiographs. ${ }^{[20]}$ However planar bone scan is less sensitive than MRI in detecting bone metastasis, almost $50 \%$ of its results are false negative and it does not accurately distinguish between pathologic and nonpathologic fractures. ${ }^{[20]}$ F-18 NaF PET is more accurate in detecting bone metastases than is planar bone scintigraphy, but it is costly and not readily available. ${ }^{[20]}$

F-18 NaF PET scan failed to reveal the tumor in the spinal process in our patient, and the lesion could be seen only on MRI. It is very unlikely for an adenocarcinoma metastasis to reach the size of $24 \times 21 \mathrm{~mm}$ in three weeks, so it can be considered as a false negative result. This is consistent with the literature suggesting contrast enhanced MRI of the entire spine is the investigation of choice in patients with known malignancy and suspected spinal disease. ${ }^{[21]}$

Major surgical procedures should be considered only for patients who are expected to survive more than three months. ${ }^{[22]}$ The patient's life expectancy, overall tumor load, quality of life and other treatment options should be assessed before surgical planning. ${ }^{[23,24]}$

The presented case is very uncommon in terms of its unique localization. We could not find any solitary spinous process metastasis reported in the English literature. Cancer patients especially if they have prior known metastases should be carefully investigated thoroughly for spinal column involvement even with a vague low back pain.

\section{Declaration of conflicting interests}

The authors declared no conflicts of interest with respect to the authorship and/or publication of this article.

\section{Funding}

The authors received no financial support for the research and/or authorship of this article.

\section{REFERENCES}

1. Guillevin R, Vallee JN, Lafitte F, Menuel C, Duverneuil NM, Chiras J. Spine metastasis imaging: review of the literature. J Neuroradiol 2007;34:311-21.

2. Healey JH, Brown HK. Complications of bone metastases: surgical management. Cancer 2000;88:2940-51.

3. Coleman RE. Clinical features of metastatic bone disease and risk of skeletal morbidity. Clin Cancer Res 2006;12:6243s-6249s.

4. Schick U, Marquardt G, Lorenz R. Intradural and extradural spinal metastases. Neurosurg Rev 2001;24:1-5.

5. Heary RF, Bono CM. Metastatic spinal tumors. Neurosurg Focus 2001;11:e1.

6. Nottebaert M, von Hochstetter AR, Exner GU, Schreiber A. Metastatic carcinoma of the spine. A study of 92 cases. Int Orthop 1987;11:345-8.

7. Gokaslan ZL, York JE, Walsh GL, McCutcheon IE, Lang FF, Putnam JB Jr, et al. Transthoracic vertebrectomy for metastatic spinal tumors. J Neurosurg 1998;89:599-609.

8. Perrin RG, McBroom RJ. Anterior versus posterior decompression for symptomatic spinal metastasis. Can J Neurol Sci 1987;14:75-80.

9. Gilbert RW, Kim JH, Posner JB. Epidural spinal cord compression from metastatic tumor: diagnosis and treatment. Ann Neurol 1978;3:40-51.

10. Kang HY, Jeon SH, Lee SH, Shin SW, Lee HY. Percutaneous thoracic disc decompression with laser-assisted spinal endoscopy under CT fluoroscopy guidance. Eklem Hastalik Cerrahisi 2005;2:88-95.

11. Onimus M, Papin P, Gangloff S. Results of surgical treatment of spinal thoracic and lumbar metastases. Eur 
Spine J 1996;5:407-11.

12. Botterell EH, Fitzgerald GW. Spinal cord compression produced by extradural malignant tumours; early recognition, treatment and results. Can Med Assoc J 1959;80:791-6.

13. Boriani S, Weinstein JN, Biagini R. Primary bone tumors of the spine. Terminology and surgical staging. Spine (Phila Pa 1976) 1997;22:1036-44.

14. Tokuhashi Y, Matsuzaki H, Oda H, Oshima M, Ryu J. A revised scoring system for preoperative evaluation of metastatic spine tumor prognosis. Spine (Phila Pa 1976) 2005;30:2186-91.

15. Tomita K, Kawahara N, Kobayashi T, Yoshida A, Murakami H, Akamaru T. Surgical strategy for spinal metastases. Spine (Phila Pa 1976) 2001;26:298-306.

16. Algra PR, Heimans JJ, Valk J, Nauta JJ, Lachniet M, Van Kooten B. Do metastases in vertebrae begin in the body or the pedicles? Imaging study in 45 patients. AJR Am J Roentgenol 1992;158:1275-9.

17. Batson OV. The function of the vertebral veins and their role in the spread of metastases. Ann Surg 1940;112:138-49.

18. Rodichok LD, Harper GR, Ruckdeschel JC, Price A, Roberson G, Barron KD, et al. Early diagnosis of spinal epidural metastases. Am J Med 1981;70:1181-8.

19. Charkes ND, Sklaroff DM, Young I. A critical analysis of strontium bone scanning for detection of metastatic cancer. Am J Roentgenol Radium Ther Nucl Med 1966;96:647-56.

20. Schirrmeister H, Glatting G, Hetzel J, Nüssle K, Arslandemir C, Buck AK, et al. Prospective evaluation of the clinical value of planar bone scans, SPECT, and (18)F-labeled $\mathrm{NaF}$ PET in newly diagnosed lung cancer. J Nucl Med 2001;42:1800-4.

21. Loughrey GJ, Collins CD, Todd SM, Brown NM, Johnson RJ. Magnetic resonance imaging in the management of suspected spinal canal disease in patients with known malignancy. Clin Radiol 2000;55:849-55.

22. National Collaborating Centre for Cancer (UK). Metastatic Spinal Cord Compression: Diagnosis and Management of Patients at Risk of or with Metastatic Spinal Cord Compression. Cardiff (UK): National Collaborating Centre for Cancer (UK); 2008.

23. Simşek S, Belen D, Yiğitkanli K, Aciduman A, Bavbek M. Circumferential total resection of cervical tumors: report of two consecutive cases and technical note. Turk Neurosurg 2009;19:153-8.

24. Gundes H, Guven O, Mecikoglu M, Sevinc T, Yalcin S. Stabilization and decompression of the metastatic spinal tumor with Cotrel-Dubousset instrumentation. Eklem Hastalik Cerrahisi 1994;1:47-52. 